\title{
Bringing the MCH Life Course Perspective to Life
}

\author{
Cheri Pies $\cdot$ Milton Kotelchuck
}

Published online: 19 December 2013

(c) Springer Science+Business Media New York 2013

It has been 10 years since Michael $\mathrm{Lu}$ and Neal Halfon published their landmark article on the MCH Life Course Perspective in this journal [1]. Since that time, the work of integrating the life course perspective into the field of maternal and child health has taken off. MCH Life Course theory and the emerging preconception care movement have reanimated earlier, historical conversations in $\mathrm{MCH}$ about health equity and social determinants of health and redirected our attention to the importance of early experiences and their influence on health longitudinally [2-8]. In fact, life course orientation has been a part of the $\mathrm{MCH}$ DNA for a long time as illustrated eloquently by Pauline Stitt who worked with the Children's Bureau in 1960

$\mathrm{MCH}$ does not raise children, it raises adults. All of tomorrow's productive, mature citizens are located someplace along the $\mathrm{MCH}$ continuum. They are at some point in their creation either being conceived or born or nurtured for the years to come. There is very little genuine perception that mature people come from small beginnings, that they've had a perilous passage every moment of the way. All the population, everybody of every age, were at one time children. And they bring to their maturity and old age the strength and scars of an entire lifetime. [9]

\section{Pies $(\square)$}

School of Public Health, University of California, Berkeley, 279

University Hall, Berkeley, CA 94720, USA

e-mail: cpies@berkeley.edu

\section{Kotelchuck}

MGH Center for Child \& Adolescent Health Research and Policy, MassGeneral Hospital for Children, and Harvard Medical School, Boston, MA, USA

e-mail: mkotelchuck@partners.org
Yet, historical efforts had not proven successful in optimizing $\mathrm{MCH}$ population health or reducing disparities. We recognized that disparities in birth outcomes and in health generally cannot be reduced and/or equity of opportunities achieved if we only continued to focus on our clinical efforts of the recent years-more prenatal care, more medical homes, better deliveries-however valuable those may be. The Lu and Halfon article [1] helped promote a paradigm shift in our field's thinking about how to achieve optimal maternal and child health-a paradigm shift which acknowledges the importance of quality preconception, prenatal and obstetric care as essential to good birth outcomes, but recognizes and institutionalizes the significant role that stress and cumulative pathways, health inequities, and the social, economic and environmental determinants of health play in influencing disparities across one's life course. Moreover, recent advances in basic biological sciences, epigenetics, the cumulative effects of stress, and epidemiologic life course research have provided the $\mathrm{MCH}$ field with a stronger scientific basis for embracing and reinforcing life course concepts [10-13].

Despite this movement in the field, these advances in life course conceptualization and science have not been enough to move our field forward. That is, we have a good handle on the theory and values related to life course, but until recently, we did not know how to move from theory about life course to the actual practice of life course. Nor did we have the necessary political or professional will to make this paradigm shift a reality. This Special Issue on Advancing MCH Life Course reflects how far we have come.

In 2008, 5 years after the publication of the $\mathrm{Lu}$ and Halfon article Cheri Pies and Milt Kotelchuck worked with Michael Lu and Padmini Parthasarathy to organize and convene a National MCH Life Course meeting in Oakland, 
CA. At that time, there were just a few life course-oriented projects being implemented [14-17], and the fundamental ideas of life course theory were only beginning to gain credibility in $\mathrm{MCH}$ circles. This meeting, funded by The California Endowment with additional support from Contra Costa Health Services, was attended by a group of 25 community, state, and national MCH leaders. The meeting was an effort to jumpstart life course in the $\mathrm{MCH}$ field with a formal focus on its theory, practice, policy, research, and education and training. The work of the participants at that meeting involved setting an agenda to move the needle on the application of the life course perspective in our field.

This first new era MCH Life Course meeting felt like a good start. We had pulled together a team of enthusiastic and influential early adopters. But, in truth, at the end of the meeting, we felt a bit let down. No great proclamations were made, no new manifestos were written; we didn't have anything that looked like a best practice yet. In fact, as with many meetings of this kind, it was not immediately obvious how we would go about translating the MCH Life Course ideas into practice. Despite this sense of uncertainty of what would come next, we wrote and produced two brief monographs, one describing the meeting (its objectives, key themes, discussion points, recommendations for next steps), and the other focusing on what MCH Life Course meant for policy and research in the field $[18,19]$.

We then set out to work with other $\mathrm{MCH}$ partners to accomplish the specific action steps that were identified at that National $\mathrm{MCH}$ Life Course meeting. These action steps included (1) mapping the landscape of what was currently being done and sharing it; (2) educating practitioners, policy makers and others about the life course perspective offering multiple points for intervention; (3) utilizing health equity as a guiding principle; (4) developing a set of life course related materials for a toolbox for practitioners, academics, and policy makers; and (5) supporting priorities for changes in $\mathrm{MCH}$ policies with a life course, social determinants of health, and health equity focus. In addition, meeting participants agreed it was essential to educate policy makers responsible for funding Title V programs about the importance of integrating the life course perspective into the scopes of the work required of Title V grantees, and promoting a framework based on the life course approach at the national, state and local levels.

Translating life course theory into practice in multiple $\mathrm{MCH}$ arenas proved to be much harder than we had thought. MCH Life Course was a great theory and very consistent with our $\mathrm{MCH}$ values and history. But at that time, a few things were still missing: (1) a broad acrossthe-board willingness to work on the new MCH Life Course approaches, (2) a toolbox that could give form and direction to emerging MCH Life Course initiatives, and (3) a published literature documenting efforts, successes and lessons learned. Nonetheless, within a year of our National $\mathrm{MCH}$ Life Course meeting, MCH Life Course seemed to gain traction. Across the country we started to see new ideas for MCH Life Course research, policy, education and practice emerging; innovative projects initiated; and a genuine openness and enthusiasm among colleagues at all levels of $\mathrm{MCH}$ to what was possible.

It was around this time that Dr. Peter Van Dyck, the former Associate Administrator of the Maternal and Child Health Bureau, brought greater attention to the life course perspective at the federal and federal state partnership levels. He commissioned and released the influential concept paper by Fine and Kotelchuck in 2010, "Rethinking MCH: The Life Course Model as an Organizing Framework" [20]. And he encouraged Title V agencies, and the MCH Bureau itself, to adopt a more life course orientation.

Our community was hungry for information, including publications, on life course practice, and not simply more studies and theories. The idea for this Special IssueAdvancing $\mathrm{MCH}$ Life Course-started to percolate sometime in 2010, not long after the release of the Fine and Kotelchuck concept paper. As we attended meetings around the country, we talked with people who were excited about transforming their $\mathrm{MCH}$ programs with a life course perspective; or who were already applying the life course concepts to research and policy and practice; or who recognized that the programs they had in place in their local health departments already fit into the life course framework, but they hadn't been calling them that. We found that in spite of the growing attention to and active national conversations about the application of the life course perspective in many realms of maternal and child health, there was limited literature available for people in the trenches, $\mathrm{MCH}$ practitioners, policy makers, students, and others; a literature that could serve to institutionalize and guide these ideas, innovative efforts, and achievements.

We began the work on this Special Issue in 2011 with support and encouragement from Donna Peterson, the former Editor of the Maternal and Child Health Journal. This special issue, coming 5 years after our 2008 National MCH Life Course Meeting, is a logical extension of all the prior life course work that has occurred up to this point in time. It is the culmination of a dream for us that began in 2008 . We believe this Special Issue offers practitioners, policy makers, educators, researchers and others an opportunity to share their best work and creates an important forum for their voices, their work, their successes and their challenges. This special issue is a step forward in our efforts to build an MCH Life Course learning community.

When the call for abstracts went out, the response was substantial; there were many MCH Life Course activities 
underway. The work that people were doing was innovative and groundbreaking. We were excited to read the manuscripts and are pleased to have been able to include so many of the manuscripts in this MCH Journal Special Issue. We want to thank our team of peer-reviewers who helped enrich these articles with their comments, suggestions, and insights.

We have divided this Special Issue into six specific sections-Theory, Local Practice, State Practice and State Policy, Education, Domain Commentaries, and Research. Each section contains articles that make an important contribution to the work in that arena and provide new ideas and ways of addressing key issues in our field through a life course lens.

In his opening editorial, Michael Lu, the Associate Administrator of the Maternal and Child Health Bureau, encourages us to reflect upon "where do we go from here?" to make life course real. He challenges us to think beyond discovery to intervention research, to move from isolated to collective impact, and to move beyond remediation to capacity formation [21]. In our first section on Theory, Halfon and colleagues offer a comprehensive and breathtaking historical overview of Life Course Health Development that sets the stage for future continued developments [22]. And Braveman crafts a compelling discussion of health equity and the ways in which the life course approach might bring us closer to it [23].

In the next section on Local Practice, where some of the greatest innovations in MCH Life Course are occurring, you will find five outstanding articles that address different, yet complementary, ways of advancing the life course approach in $\mathrm{MCH}$ practice settings. Shrimali et al. [24] and Parthasarathy et al. [25] describe two dynamic local health department programs designed from a life course perspective that tackle disparities in birth outcomes from slightly different vantage points, community organizing and financial empowerment respectively. Brady and Johnson [26] demonstrate how a Healthy Start Program can effectively employ the life course concepts to enhance the program; and Cheng and Solomon [27] offer insights into translating life course theory into pediatric clinical settings. Finally, in this section, Allen and colleagues [28] demonstrate an innovative cross-sectoral approach to reducing maternal stress and pregnancy risk through improving and addressing access to housing for homeless pregnant women.

We felt it was important to bring attention to the life course work that is taking place at the State level. Here we include two articles, both from Wisconsin, one focusing on a regional funding initiative by Rohan et al. [29] and the other identifying the challenging organizational work of institutionalizing this paradigm shift in a state Title $\mathrm{V}$ agency by Frey et al. [30].
We have also included two articles by Edwards et al. [31] and Anderson et al. [32] that describe the ways that two different programs have gone about incorporating life course theory into their curricula. These articles offer readers concrete ideas for how they might approach curriculum development and content for students and practitioners in a variety of settings.

In the next section, entitled "Domain Commentaries", readers will find inspiration, information, and innovation to guide their life course thinking and practice in several important $\mathrm{MCH}$ arenas-nutrition [33], adolescence [34], and children with special health care needs [35].

Finally, we offer readers a closer look at some of the innovative research that is starting to emerge with a focus on longitudinally linked multi-generational vital records [36] and maternally linked birth cohort data sets [37], which is improving both the content and practice of doing longitudinal life course research. We close this section of the Special Issue with a dynamic article by Russ et al., [38] that challenge us to think critically about the implications of the life course approach to health development for our maternal and child health research agenda.

We bring you this Special Issue to promote the germination of new and innovative MCH Life Course approaches to theory, policy, local and state practice, research, education and training. We hope that these articles are valuable to our community of scholars, practitioners, clinicians, and others as we begin to develop a MCH Life Course practice literature. We also hope that the work contained in this Special Issue stimulates new and better practice-new MCH Life Course learning.

And into the future, we hope that by 2018, 15 years after the publication of the Lu and Halfon [1] article, we will see an MCH community that has fully embraced an MCH Life Course perspective with programs that approach a child's development holistically; endorse an intergenerational continuity framework; address the social determinant roots, health inequities, and current facilitators of disparities; and fully engage communities with local, State and national $\mathrm{MCH}$ and associated organizations. This Special Issue offers each of us an opportunity to return to our field's social determinant and longitudinal roots, and inspires us to develop $\mathrm{MCH}$ practice initiatives that will genuinely improve birth outcomes, reduce disparities, and optimize health for all of our children and their families.

Acknowledgments The Editors of this Special Issue would like to extend a very special thanks to Carly E. Strouse MPH who provided extensive assistance, diligent oversight, and constant coordination of our efforts that brought us to the successful publication of this Special Issue. In addition, we would like to thank our team of peer reviewers who offered their scholarly insights and constructive feedback, and to the staff at Springer Publishing for their support and outstanding work. 


\section{References}

1. Lu, M. C., \& Halfon, N. (2003). Racial and ethnic disparities in birth outcomes: A life-course perspective. Maternal and Child Health Journal, 7, 13-30.

2. Moos, M. K. (2004). Preconceptional health promotion: Progress in changing a prevention paradigm. The Journal of Perinatal and Neonatal Nursing, 18(1), 2-13.

3. Halfon, J., \& Hochstein, M. (2002). Life course health development: An integrated framework for developing health, policy, and research. The Milbank Quarterly, 80, 79-433.

4. Lu, M. C., Kotelchuck, M., Culhane, J. F., Hobel, C. J., Klerman, L. V., \& Thorp, J. M., Jr. (2006). Preconception care between pregnancies: The content of internatal care. Maternal and Child Health Journal, 10, S107-S122.

5. Shonkoff, J. P., Boyce, W. T., \& McEwen, B. S. (2009). Neuroscience, molecular biology, and the childhood roots of health disparities: Building a new framework for health promotion and disease prevention. Journal of the American Medical Association, 301(21), 2252-2259.

6. Kuh, D., Ben-Shlomo, Y., Lynch, J., Hallqvist, J., \& Power, C. (2003). Life course epidemiology. Journal of Epidemiology and Community Health, 57, 778-783.

7. Braveman, P., \& Barclay, C. (2009). Health disparities beginning in childhood: A life-course perspective. Pediatrics, 124(Supplement), S163-S175.

8. Collins, J. W., David, R. J., Prachand, N. G., \& Pierce, M. L. (2003). Low birth weight across generations. Maternal and Child Health Journal, 7, 229-237.

9. http://www.mchb.hrsa.gov/timeline/resources.htm.

10. Barker, D. J. P. (1990). The fetal and infant origins of adult disease. British Medical Journal, 301, 1111.

11. Ben-Shlomo, Y., \& Kuh, D. (2002). A life course approach to chronic disease epidemiology: Conceptual models, empirical challenges and interdisciplinary perspectives. International Journal of Epidemiology, 31, 285-293.

12. Hall, S. (2007). Small, Thin: The controversy over the fetal origins of adult health. New Yorker, 19 Nov.

13. Lynch, J., \& Smith, G. D. (2005). A life course approach to chronic disease epidemiology. Annual Review of Public Health, 26, 1-35.

14. Pies, C., Parthasarathy, P., \& Posner, S. (2012). Integrating the life course perspective into a local maternal and child health program. Maternal and Child Health Journal, 16(3), 649-655.

15. Maternal and Adolescent Health, Los Angeles County Public Health Department, http://publichealth.lacounty.gov/mch/Repro ductiveHealth/PreconceptionHealth/PreconceptionHealth_rev.htm.

16. The Los Angeles Moms and Babies Project, http://publichealth. lacounty.gov/mch/LAMB/LAMB.html.

17. Northern Manhattan Perinatal Partnership, http://www.sisterlink.com.

18. Fine, A., Kotelchuck, M., Adess, N., Pies, C. (2009). Policy brief. A new agenda for $\mathrm{MCH}$ policy and programs: Integrating a Life Course Perspective. Martinez, CA. Contra Costa Health Services. http://www.cchealth.org/groups/lifecourse/pdf/2009_10_policy_ brief.pdf.

19. Pies, C., Parthasarathy, P., Kotelchuck, M., Lu, M. (2009). Making a paradigm shift in maternal and child health: A report on the National MCH Life Course Meeting. Martinez, CA. Contra Costa Health Services.

20. Fine, A., Kotelchuck, M., Rethinking, M. C. H. (2010). The life course model as an organizing framework. Rockville, MD: Health and Human Services, Health Resources and Services Administration, Maternal and Child Health Bureau.

21. Lu, M. C. (2013). Improving maternal and child health across the life course: Where do we go from here? Maternal and Child Health Journal.
22. Halfon, N., Larson, K., Lu, M. C., et al. (2013). Life course health development: Past, present, and future. Maternal and Child Health Journal. doi:10.1007/s10995-013-1346-2.

23. Braveman, P. (2013). What is health equity-And how does a life course approach take us further toward it? Maternal and Child Health Journal. doi:10.1007/s10995-013-1226-9.

24. Shrimali, B. P., Luginbuhl, J., Malin, C., et al. (2013). The building blocks collaborative: Advancing a life course approach to health equity through multi-sector collaboration. Maternal and Child Health Journal. doi:10.1007/s10995-013-1278-x.

25. Parthasarathy, P., Dailey, D., \& Pies, C. (2013). Building economic security today: Making the health-wealth connection in Contra Costa County's maternal and child health programs. Maternal and Child Health Journal. doi:10.1007/s10995-013-1309-7.

26. Brady, C., \& Johnson, F. (2013). Integrating the life course into $\mathrm{MCH}$ service delivery: From theory to practice. Maternal and Child Health Journal. doi:10.1007/s10995-013-1242-9.

27. Cheng, T., Solomon, B. (2013). Translating life course theory to clinical practice to address health disparities. Maternal and Child Health Journal. doi:10.1007/s10995-013-1279-9.

28. Allen, D., Feinberg, E., \& Mitchell, H. (2013). Bringing life course home: A pilot to reduce pregnancy risk through housing access and family support. Maternal and Child Health Journal. doi:10.1007/s10995-013-1327-5.

29. Rohan, A. M., Onheiber, P. M., Hale, L., et al. (2013). Turning the ship: Making the shift to a life-course framework. Maternal and Child Health Journal. doi:10.1007/s10995-013-1225-x.

30. Frey, C. A., Farrell, P. M., Cotton, Q., Lathen, L., \& Marks, K. (2013). Wisconsin's lifecourse initiative for healthy families: Application of the maternal and child health life course perspective through a regional funding initiative. Maternal and Child Health Journal. doi:10.1007/s10995-013-1271-4.

31. Edwards, K., Towle, P., \& Levitz, B. (2013). Incorporating life course theory and social determinants of health into the LEND curriculum. Maternal and Child Health Journal. doi:10.1007/ s10995-013-1283-0.

32. Anderson, L., Schroth, M., Marcus, M., et al. (2013). The development and implementation of an interdisciplinary on-line academic course using a life course perspective. Maternal and Child Health Journal. doi:10.1007/s10995-013-1282-1.

33. Herman, D., Baer, M. T., Adams, E., et al. (2013). Life course perspective: Evidence for the role of nutrition. Maternal and Child Health Journal. doi:10.1007/s10995-013-1280-3.

34. Shlafer, R., Hergenroeder, A. C., Emans, S. J., et al. (2013). Adolescence as a critical stage in the MCH life course model: Commentary for the leadership education in adolescent health (LEAH) interdisciplinary training program projects. Maternal and Child Health Journal. doi:10.1007/s10995-013-1243-8.

35. Bethell, C., Newacheck, P., Fine, A., et al. (2013). Optimizing health and health care systems for children with special health care needs using the life course perspective. Maternal and Child Health Journal. doi:10.1007/s10995-013-1371-1.

36. Kramer, M. R., Dunlop, A. L., \& Hogue, C. J. R. (2013). Measuring women's cumulative neighborhood deprivation exposure using longitudinally linked vital records: A tool for life course MCH research. Maternal and Child Health Journal. doi:10.1007/ s10995-013-1244-7.

37. Chapman, D. A., Gray, G. (2013). Developing a maternally linked birth dataset to study the generational recurrence of low birthweight in Virginia. Maternal and Child Health Journal. doi:10.1007/s10995-013-1277-4.

38. Russ, S., Larson, K., Tullis, E., \& Halfon, N. (2013). A lifecourse approach to health development: Implications for the maternal and child health research agenda. Maternal and Child Health Journal. doi:10.1007/s10995-013-1284-2. 